\title{
Discursive Contextures of Science: Euro/West-Centrism and Science and Technology Studies
}

\author{
AMit Prasad \\ UNIVERSITY OF MISSOURI
}

\begin{abstract}
Science and Technology Studies (STS) by the very act of showing the multiplicity, contingency, and context-dependence of scientific knowledge and practice, provincialized modern science. Postcolonial interventions within STS have pursued this goal even further. Nevertheless, Euro/West-centrism continues to inflect not only scientific practices and lay imaginaries, but also sociological and historical analyses of sciences. In this article, drawing on my own training within STS - first under J.P.S. Uberoi, who was concerned with structuralist analysis of modernity and science, and thereafter under Andy Pickering, when we focused on material agency and temporal emergence and extensively engaged with Actor Network Theory - I emphasize the continuing role of Euro/West-centric discourses in defining the "self" and the "other" and in impacting epistemological and ontological interventions. More broadly, building on a concept of Michael Lynch's, I call for excavation and analysis of discursive contextures of sciences. In the second section of the article, through a brief analysis of embryonic stem cell therapy in a clinic in Delhi, I show how with shifting transnational landscape of technoscience certain discursive contextures are being "deterritorialized" and left "stuttering."
\end{abstract}

\section{Keywords}

discursive contextures; territorialization; Euro/West-centrism; de/ post-colonial, modernity

\section{Introduction}

In the second half of the 1990s, when I was completing my Masters in Sociology at Delhi School of Economics, India, there was excitement, but little engagement with Science and Technology Studies (STS). There were only three or four STS books in our library. Two of them, Karin Knorr-

\footnotetext{
. Amit Prasad, Email: prasada@missouri.edu
}

Copyright (c) 2016 (Amit Prasad). Licensed under the Creative Commons Attribution Non-commercial No Derivatives (by-nc-nd). Available at estsjournal.org. 
Cetina's The Manufacture of Knowledge (Knorr-Cetina 1981) and Bruno Latour and Steve Woolgar's Laboratory Life (Latour and Woolgar 1986), fascinated me. The relocation of "the problem of facticity" "as a problem of (laboratory) fabrication" (Knorr-Cetina 1981, 3) was a goal that I wanted to pursue in my research. However, my concerns, in part because of my postcolonial location and in part because of my training in sociology of science at Delhi School, were somewhat different.

J. P. S. Uberoi--one of the first proponents of alternative sciences--initiated me into sociology of science. Uberoi's conceptualization of an alternative science cannot be simplistically conflated with his Indian/non-Western/postcolonial identity. Uberoi is not an advocate of identity politics. He critiqued the notion of boundary and proposed the concept of frontier in understanding societies. ${ }^{2}$ For Uberoi, Goethe's theory of colors, in contrast to that of Newton, presented the exemplar of an alternative science that was non-dualist and non-linear (Uberoi 1984, 2002). Parallel to the emergence of STS, Uberoi emphasized the role of the social in constituting science and modernity (Uberoi 1978b). He even conducted experiments based on Goethe's theory of colors to study the latter's veracity. Nevertheless, his concern, in contrast to those prominent in STS, was not empirical investigations of sciences.

"To study the nature of things," Uberoi argued, "one should study not only systems of things" but also "systems of signs" (Uberoi 1984, 41), which, according to him, would allow us to uncover "the structure of the modernist regime" (Uberoi 2002, 49, emphasis added). The urgency of such an investigation, for Uberoi, is inseparable from the necessity of a non-Western/Indian intervention in science, and this is imprinted in the first sentences of his book: "India as a culture area will be nowhere...in the world of knowledge, the sciences and the arts if it does not first defy the European monopoly of the scientific method, established in modern times" (Uberoi 1984, 9). My initiation into sociology of science was thus founded on an intellectual tension. On the one hand, the claim, "whatever characteristics of the social one cares to identify" are "themselves remade in practice" (Pickering 1995, 33) seemed not only plausible, but also the right path to follow. On the other hand, I found it telling how little STS engaged with concerns such as that of Uberoi, which, in spite of my disagreements with Uberoi's structuralist approach, resonated with me. Is this merely an incidental elision? Are such exclusions artifacts of Euro/West-centric discursive constructions?

STS, by the very act of showing the multiplicity, contingency, and context-dependence of scientific knowledge and practice, provincialized modern science. ${ }^{3}$ Postcolonial interventions within STS have pursued this goal even further (Harding 1994, 1998, Abraham 2000, 2006,

"Uberoi's conceptualization of frontier has resonance with theorization of "boundary objects" (Star and Griesemer 1989, Bowker and Star 1999, Fujimura 1992) and "trading zones" (Galison 1996). However, for Uberoi, frontier is a structural property of "place": "frontier is an autonomous region which represents the conjunction, the unity and the opposition of two or more other regions" (Uberoi 1978a, 74).

${ }^{3}$ It is relevant to note that Hans-Georg Gadamer, with whose quote Dipesh Chakrabarty starts his book, Provincializing Europe, saw modern science as an exception to his broader lament about provincializing of Europe: "Europe...since 1914 has become provincialized...only the natural sciences are able to call forth a quick international echo" (Chakrabarty 2000, 3, emphasis added). 
Anderson 2002, 2009):* Modern science, which was commonly accepted as a "culture of no culture" and as such became "a metaphor for the triumph of universal reason," has been shown to be context dependent, temporally emergent, and multiple." In short, modernity and modern science, which have undergirded not only intellectual engagements but also colonial and postcolonial administrations, are relegated to the category of "never been." How do we then make sense of, for example, Uberoi's (and several others') engagement with European as well as alternative modernity and science? Does it reflect a work of purification propelling further purification? Or, is it a work of translation that by putting non-dualist knowledge/science within European modernity decenters (and implicitly hybridizes) Western modernity, thereby creating space for alternative sciences? I suggest it is both and this is so, at least in part, because of the discursive force of Euro/West-centrism.

The modernist work of purification may indeed have led to proliferation of hybrids, as Latour suggests (Latour 1993); however, Euro/West-centrism ensured that in the non-West as well as the West such proliferation remained hierarchically tied to and, often, even submerged within further purifications. In spite of his fierce critique of European modernity and modern science, Uberoi, for example, presents non-dualism and the "semiological method"-important elements of Indian philosophy, as he himself admits (Uberoi 1978b) — as an exemplification of "the other mind of Europe" (Uberoi 1984). ${ }^{6}$ Do the empirical approaches of STS allow us to transcend the discursive force of Euro/West-centrism? How are we to understand, for example, John Law's claim in relation to the great divide between the West and the non-West (or that between modern and primitive)? "[T]he significance of Latour's analysis of the role of the printing press," Law argues, "is that its invention...goes some way to explaining both the hegemony of the west and the 'great divide' between primitive and modern" (Law 1986, 255-6).

Building on a concept of Michael Lynch's (Lynch 1991), I call for excavation and analysis of discursive contextures of sciences. In particular, I suggest the need to deconstruct Euro/Westcentrism in order to foreground and move beyond Orientalist "imaginative geographies"--i.e. intensification of a sense of the self and the other "by dramatizing the distance and difference between what is close and what is far away" (Said 1979, 55). The discursive clearing brought about by deconstruction of Euro/West-centrism allows us to excavate entangled histories and cultures of sciences (Prasad 2014b, a). In the last section of this essay, through a brief discussion of embryonic stem cell therapy in a clinic in Delhi, I show how with shifting transnational landscape technoscientific discourses are being "deterritorialized" and left "stuttering." " I suggest

- There is a large body of work under the rubric of postcolonial science studies at present. Along with a reader (Harding 2011) four special issues of journals have focused on postcolonial science studies (Anderson 2002, McNeil 2005, Abraham 2006, Seth 2009).

"Sharon Traweek uses the phrase "culture of no culture." (Traweek 1988) and Gyan Prakash shows how modern science became a metaphor for the triumph of reason (Prakash 1999). STS has had a longstanding debate in relation to erasure of location and culture within scientific practice and knowledge. For insightful analyses of this debate see (Franklin 1995, Pickering 1992).

"It should be emphasized that for Uberoi "self-identity is never self-explanatory but is rather a free gift of the other; and that the unity of self...is truly first and last reducible to the other of its other(s)" (Uberoi 2002, 115).

"For detailed conceptualization and discussion of "deterritorialization" and "stuttering" see (Deleuze and Guattari 1987, Deleuze 1997). 
that, instead of ignoring such technoscientific practices, we should study them to unravel how a rapidly changing transnational landscape of technoscience is troubling normative (largely Westcentered) discourses through which we not only assess true/false and right/wrong but also define self/other.

\section{Discursive Contextures, Euro/West-Centrism, and STS}

The meaning as well as venues of the "laboratory" have been contested and have shifted through history (Shapin 1988, Hannaway 1986). Nevertheless, the physical and social setting of "the house of experiment," which eventually became the laboratory, not only defined what constitutes credible knowledge, but also the social etiquettes and material constituents of how scientific knowledge should be produced (Shapin 1988, Shapin and Schaffer 1985).

Lynch, drawing on ethnomethodology, brought to light the "topical contextures" of laboratory practices (Lynch 1991). "The topic of laboratory space," Lynch argues, "is not primarily concerned with the 'naming' or 'labeling' of space but with the grammars of spatial concepts associated with particular practices" (Lynch 1991, 53). He focused on two such topical contextures-opticism and digitality. Although Lynch draws upon Michel Foucault's writings to frame his argument about contextures, he explicitly refrains from using the broader Foucauldian conception of discourse. ${ }^{8}$

Discourses, Foucault has shown, constitute not only subjects, but also spaces and gaze (e.g. the panopticon) and truth (Foucault 1979, 1994, 1980). ${ }^{9}$ My concern is discursive contextures of science i.e. "territorialization" of discourses of science. ${ }^{10}$ For Gilles Deleuze and Felix Guattari "territory" is not pre-given; "territorializing" involves marking of functions, rhythms, rituals, milieus, etc. and "becoming-expressive" (Deleuze and Guattari 1987). Discourses, similarly, are territorialized and imbued with historically constituted understanding of self/other and with norms, values, and practices that are tied to particular "territories" (e.g. West/non-West, science/non-science, etc.). Territorialization (and "de/re-territorializations"), as Deleuze and Guattari further argue, present "lines of flight" that are "not indeterminate but rather...determined differently" (Deleuze and Guattari 1987, 322). Indeed, Uberoi's deterritorialization and reterritorialization of the "semiological method" as "the other mind of Europe" reflects a line of flight. And this is true with regard to Law's and Latour's

\footnotetext{
- Lynch writes: "Many of Foucault's interpreters use his explications...to index an entire historic arrangement of power/knowledge...For an ethnomethodological reading, however, Foucault is at his best when explicating the details of texts he appropriates, and he is least convincing when advancing a general theory of power/knowledge" (Lynch 1991, 55).

' Edward Said has shown how the Orient (and Orientalism) was, and continues to be, discursively constituted (Said 1979). Judith Butler, on the other hand, shows that not only gender, but also biological sex cannot be extricated from constitutive discourses (Butler 1990). There is also a long line of intellectual engagement with the role of ideology in constituting subjects, particularly within the Marxist tradition. Louis Althusser, for example, argues that individuals are interpellated by ideology, constituting the self within capitalist political economy in the process (Althusser 1971). Within science studies Itty Abraham has argued for the need to investigate the role of ideology in scientific practices (Abraham 2006).

"Within STS not only the situatedness of all knowledges has been highlighted (e.g. Haraway 1991); it has also been emphasized that geography critically transforms knowledge making (Anderson 2012).
} 
deterritorialization and reterritorialization of the "great divide" as well. However, there is a significant difference between them, which, as Uberoi's words that I quote in the following highlight, reminds us that not only epistemological/ontological interventions but also places and subjects / objects are intimately tied to discursive contextures: "The relentless logic of this general situation of spiritual travail [Euro/west-centric divide based on modern science]...inevitably produces in me for one a shameful inferiority" (Uberoi 1978b, 14). ${ }^{11}$

A significant reason for the continued impact of Euro/West-centrism is that we ignore the role of discourses in constituting subjects and places and in impacting the practices and imaginaries of scientists and of STS scholars. The empirical focus of STS has, indeed, been an important and necessary intervention, which, as discussed earlier, even provincializes modern science, but it is not enough. ${ }^{2}$ The Euro/West-centrism that continues to inflect STS is not incidental; it reflects a play of, to use a Derridian neologism, "supplementarity." How else are we to understand, for example, deployment of the category of "great divide," even if it is "freed from...debates about 'rationality,' 'relativism,' 'culture,' and the extent of the Great Divide" (Latour 1987, 213)? When confronted with the categories of West/non-West, instead of hybrids/hybridization, we are left with "great divide." Doesn't this reflect imbrication within Euro/West-centric discourse? And can it be overcome simply by an empirical and descriptive analysis?

Latour, and ANT more generally, have been insistent on the need to describe and call for a politics of addition of actants (rather than critique) - a strategy that I broadly agree with, but its limitations are worth noting as well. "Either the networks that make possible a state of affairs are fully deployed--and then adding an explanation will be superfluous —or we 'add an explanation' stating that some other actor or factor should be taken into account, so that it is the description that should be extended one step further" (Latour 2005, 137, emphasis in the original). Latour is clear in his choice: "Much like 'safe sex' sticking to description protects against the transmission of explanations...contrary to the scholastic proverb, there is science only of the particular" (Latour 2005, 137).

Consequently, if one follows ANT, there is no way to extend, say, the disciplining of ships and the printing press to an explanation of the great divide, even in the sense in which ANT scholars describe it. Disciplining of ships or printing press, for example, has no necessary connection to domination of the world. Empirically and descriptively, the categories of the West and the non-West are unsustainable and particular explanations of the great divide (if there is

"Interestingly, when I had first discussed with Uberoi STS engagements with non-human agency his comment was telling: "Just when the 'other' starts talking they say we should talk something else."

"Michael Lynch, for example, presented a template for "postanalytic science studies," which "suggests an affiliation with the poststructuralist and postmodernist approaches," but he added that he would like to "avoid the sweeping claims about massive historical 'eras."' Lynch further argues that by the term "post" he means "a temporal (dis)placement 'after,' rather than an opposition to, the term that follows the prefix" (Lynch 1993, 312)

"The proponents of "great divide" between the West and the non-West have often emphasized material/technological difference as the reason for the divide. More recently, Prasannan Parthasarthi has argued that instead of superior rationality, science, institutions, or markets, the divergence between Europe and the rest/India can be attributed to "different competitive and ecological pressures" (Parthasarthi 2011). See also (Parthasarthi 2002). 
one) may themselves reflect specific discursive contextures. ${ }^{14}$ Such explanations prevent ANT scholarship from achieving its own goal--co-formation of places, peoples, and sciences (Latour 1987). Sanjay Subrahmanyam shows that the historical process of Portuguese travels to India/East was complex and fraught and reflected a "connected history" that calls into question accepted historical periodizations as well as geographical divides (Subrahmanyam 1993, 1997, 2005). ${ }^{15}$

My concern here is not a critique of ANT. Rather, I wish to point out how even ANT, which strictly emphasizes politics of addition and need for descriptions, cannot be free from discursive contextures. In fact, none of us can. The concept of a "centered structure," as Derrida points out, offers the basis to master an anxiety, which "is invariably the result of a certain mode of being implicated in the game, of being caught by the game" (Derrida 1978, 279). The issue, then, is not who escapes these constraints, but rather the "critical rigor with which this relation" to the dominant discourse is interrogated (Derrida 1978). Euro/West-centric discourse affects not just us, the analysts of sciences, but scientific practice as well and, as I have shown elsewhere, it results in and reinforces hierarchies that I have attempted to capture with the phrase "imperial technoscience" (Prasad 2014b).

Shifting transnational landscapes of technoscience have troubled Euro/West-centric discourses, but they continue to inflect scientific practices and imaginaries. More recently, Wenyuan Lin and John Law, drawing on their study of Chinese medicine, call for a "balance of betrayal" in STS analytics - a correlative STS to "show that a 'correlative' description of the same Chinese Medical consultation would differ markedly from one making use of 'Western' analytical assumptions" (Lin and Law 2014, 801). Yet, although questioning "Western" analytical assumptions is important and useful, merely reversing the hierarchy-- "balance of betrayal"-may do little to disturb Euro/West-centric dualist constructions. And again, instead of translations and hybrids/hybridizations, we may be left with purification of the (Western) "self" and the (non-Western) "other." Moreover, such an ontological focus may miss the complex and hierarchical dynamics of transnational flows of technoscience.

In the next section I briefly show how shifting transnational landscape is "deterritorializing" (Deleuze and Guattari 1987) normative discourses of science, which, as I further argue using another Deleuzian concept, makes these discourses "stutter" (Deleuze 1997). Deleuze, distinguishing stuttering as "an affectation of the one who speaks" from stuttering of language itself, argues, "if the system appears in perpetual disequilibrium or bifurcation, if each of its terms in turn passes through a zone of continuous vibration, then the language itself will begin to vibrate and stutter" (Deleuze 1997, 107-8). Similarly, I suggest, stem cell therapy in countries such as India result in the stuttering of normative discourses of science, ethics, and law. The stutter reflects displacement and contestation of the discourses through which we assess right/wrong and true/false.

"I wish to argue, drawing on Homi Bhabha, that different characterizations of the great divide are "metonyms of presence" and the series can be extended almost infinitely as is the case with any stereotype (Bhabha 1994).

${ }^{15}$ Interestingly, Subrahmanyam's expositions of connected histories fit much better with ANT's objectives than ANT's own analyses. 


\section{Shifting Landscape of Technoscience and Stuttering Discursive Contextures}

“There's zero evidence for what she is doing... she [i.e. Geeta Shroff, the Director of NuTech] is not published." ${ }^{16}$ Wise Young, presently the Richard Shindell Chair of Neuroscience at Rutgers University, was blunt in his indictment of embryonic stem cell research and therapy at NuTech Mediworld, New Delhi. ${ }^{17}$ For Young and several others, who spoke on a CNN documentary, the verdict is clear --the clinic is Selling a Miracle (CNN, May 16, 2012). Interestingly, Young presents a normative argument with regard to what constitutes a fact--"she is not published"-- to underscore a realist claim about embryonic stem cell research and therapy. Scientific "fact," to quote Latour, is not "qualitatively different from fiction" (Latour 1987, 42). "[A] fact is," Latour explains, "what is collectively stabilized from the midst of controversies when the activity of later papers does not consist only of criticism or deformation but also of confirmation" (Latour 1987, 42, emphasis added). But what if there are no papers? Or, if the papers are published more than a decade after the scientific claims were first made? Is there then no "fact"?

Shroff, when I interviewed her in 2012 and 2014, had told me several times that after her patent(s) come through she would publish. "I've already got 2-3 papers ready, written and set. But I can't submit"...I'd rather be criticized, but keep my patent in place," she told me. Later in that interview she added: "I believe in the old-fashioned thing, that the truth will prevail—that's my belief. And I can't help it. If can't publish, I can't publish. I'll publish next year." And she has, indeed, published a number of papers after her patents were approved in the United States.

However, within the full one year after her first article was published in the Journal of Translational Medicine (Shroff, Gupta, and Barthakur 2014), Shroff's publications have rarely been cited by other scientists. ${ }^{18}$ Hala Gabr and his colleagues confirm NuTech's results in relation to treatment of cerebral palsy patients in the American Journal of Bioscience and Bioengineering (Gabr et al. 2015). A review article on stem cell therapies published in Cell Stem Cell, co-authored by Alan Trounson and Courtney McDonald, on the other hand, singled out NuTech for criticism and characterized such studies as "very concerning for the field" (Trounson and McDonald 2015, 18). Trounson, who has himself been at the center of ethics controversies (Bharadwaj 2015), and McDonald call into question NuTech's "experimental system."

"Experimental systems," Hans-Jörg Rheinberger argues, "give laboratories their special character...as places where strategies of material signification are generated," which makes the laboratory a "manufactury of epistemic things" (Rheinberger 1997: 37). "It is through" the experimental conditions or technical objects "that the objects of investigation become entrenched and articulate themselves in a wider field of epistemic and material cultures" (Rheinberger 1997,

\footnotetext{
${ }^{16}$ NuTech Mediworld has been providing stem cell therapy for more than a decade and claims to have treated more than 1500 patients from 53 different countries (see also Prasad 2015).

"A few years before his categorical statement on CNN, Young, after observing another patient, Perry Cross, had seemed a lot less sure: "it is striking that all these improvements happened to coincide with the timing of the treatment...Does this mean that the treatment is effective? I don't know." http://sci.rutgers.edu/forum/showthread.php?100550-Stem-CellPatient-Praises-Maverick-Indian-Doctor/page5, accessed July 10, 2015.

"The citation data is drawn from Google Scholar.
} 
29). NuTech's "experimental system" is different. Shroff argues that her laboratory practices reflect "self control experiments"- since patients, prior to availing therapy at NuTech, had hardly seen any change in their condition in spite of having tried all possible treatments; any change in their condition during or after treatment at NuTech has to be the impact of embryonic stem cell therapy. These changes, as I saw firsthand, are elaborately recorded with PET and MRI scans and a host of other clinical data before and after the treatment (Prasad 2015). Such reorganization of the experimental system may inhibit the articulation and travel of "technical objects" within "epistemic cultures"-- as we have seen in some scientists' critiques of NuTech, but it has not obstructed their articulation and travel in other "material cultures." One patient, who reports his health outcomes on Reddit, was, for example, asked, "How are you sure this isn't just from the physical therapy?" He replied, "I had been doing far more intensive therapy in the USA for 5 years before going to India with never seeing any improvements."

One can dismiss NuTech's claims as selling "false hope," as has been done by some news reporters and academics. However, claims regarding the efficacy of therapy at this clinic have been striking. And such claims have not only ensured continual flow of patients to the clinic, but have also given it credibility. In 2007, for example, The Australian, reported about Sonya Smith, who was told by "Australian doctors...that she would spend the rest of her life in a wheelchair," and sensationally declared: "A Brisbane woman who was paralyzed in a car accident is walking again after receiving controversial stem-cell treatment in India." ${ }^{20}$ Patients as well as Shroff present such cases of therapy as evidence. ${ }^{21}$ As Amy Scher, who received therapy at NuTech for her Lyme condition, wrote in her blog, "Proof is not always in the Petri dish, it's in the patients" (Scher 2013, 160).22

A key concern for STS has been to unravel how science is "black-boxed"-- when "facts" are stabilized and entanglements of science with society disappear from view. With NuTech the concern is opposite: How is one to distinguish fact from fiction if the normative conditions for stabilization of claims-- i.e. those sanctioned through accepted discourses- are different from those present at NuTech? It is, however, important to emphasize that at NuTech the normative discourse of fact making in science has not been discarded; rather, it has been "deterritorialized." For example, publication of results in science journals (as the main modality of scientific knowledge production) was not discarded, but its temporality was radically transformed; concern with causality (i.e. effect of stem cells), similarly, is not discarded, but it cannot be specifically discerned, except as excess. In other words, the "epistemic/technical object," although produced in a laboratory/clinic, exists and is given credence or non-credence through simultaneous enlisting of and estrangement with the normative practices.

\footnotetext{
${ }^{19} \mathrm{https}$ / / www.reddit.com/r/IAmA/comments / qve3a/iama_quadripledric_on_my_way_to_recovery_through/, accessed August 4, 2015.

${ }^{20}$ http:/ / www.theaustralian.com.au/news/stem-cells-help-mum-walk/story-e6frg6n6-11111113342985, accessed July 10, 2015.

"The historical emergence of the laboratory as the site of experiment was accompanied by debates over whose testimony and evidence could be trusted (Shapin 1988, Dear 1985).

"Such claims are not that unusual. As Steven Epstein shows through his study of politics of knowledge in the context of AIDS, such claims reflect disputes over meaning as well as standards of evidence and they force us to move to the domain of what Epstein calls "impure science" (Epstein 1996).
} 
Patients, who have been commonly characterized in the media as desperate and gullible, are aware of the "deterritorialization" of science at the clinic. One patient, who had witnessed a change in her condition, for example, had called into question NuTech's non-publication of its results: “It doesn't make sense. I don't know why she doesn't [publish]. If it works- and I know it does-- then put it out there." ${ }_{23}$ Patients (and also Shroff) thus advocate for the normative process of "fact" making; but by simultaneously asserting the facticity of their claims, they also highlight the artificiality of the normative process. In short, patients often characterize NuTech's way of doing research and therapy—not as outside science, but as the outside of science." And in the process they not only trouble what constitutes "facts," but also the normative discourses on whose basis scientific facts are established.

Such framing, although it is specifically about NuTech, is inextricable from the hope and hype surrounding stem cell research, the shifting role of patients in defining trajectories of science, the redefinition of welfare services within neoliberalism, and the changing technocultural imaginaries of India (Franklin 2001, 2005, Cooper 2008, Cooper and Waldby 2014, Petersen 2009, Petersen and Seear 2011, Bharadwaj 2009, Salter et al. 2007). The wife of a patient highlighted some of these tensions: "Because really, HESC (Human Embryonic Stem Cell) therapy is still considered experimental...there are relatively few patient accounts one can point to and say, 'See?! Look! Here it is: indisputable proof!"' Then she added: “Not to say proof doesn't exist." And pointing to the experience of one patient in particular, she stated, "It's difficult to argue with X-rays that show healing tissue around a previously severed spine." ${ }^{\prime s}$ The stutter expressed as personal affectation (i.e., the question and exclamation marks after the word "See") cannot be extricated from the stuttering of the normative discourses of science(s), as her broader claim suggests. Different elements of science-experimental status, scientific evidence, etc.-are correlatively brought together. In the process, biomedical, ethical, legal, and cultural discourses are continually deterritorialized and reterritorialized and as such they find expression in the messy becoming of the patients (and their caregivers).

Amy Scher, for example, simultaneously presents her experience as "a body virtually reborn after stem cell therapy" (Scher 2013, 241) and classifies the process as an "ultimate self healing." In the descriptions of her therapy at NuTech, which she published as a book, Scher deterritorializes biomedical and ethical discourses and reterritorializes them, sometimes with the help of Euro/West-centric discourses. India is, thus, simultaneously constituted as a site for emergent and cutting-edge research and unchanging history and culture..$^{26}$ The front cover of her book displays an (Indian) historical monument and the back cover has an image of a cow, for example (Scher 2013). Such Euro/West-centric framing of NuTech is not unique. A 60 Minutes report in Australia, for example, starts an interview with Sonya Smith with the statement: "On

\footnotetext{
${ }^{2}$ As quoted in Stephanie Nolan, "The stem-cell black market: Delhi doctor claims wonder cures," The Globe and Mail (March 19, 2010, last updated February 26, 2013). http:/ / www.theglobeandmail.com/technology/science/the-stem-cellblack-market-delhi-doctor-claims-wonder-cures / article1316460/?page=all, accessed July 24, 2015.

${ }_{24}$ "They are not outside of language, but the outside of language" (Deleuze 1997, 5).

${ }^{25}$ https:/ / lyfebites.wordpress.com/2014/08/, accessed July 22, 2015.

${ }_{2 s}$ The tag line of her book, printed on the cover, states, "A true story of embryonic stem cells, Indian adventures, and ultimate self-healing" (Scher 2013).
} 
the ancient streets of Delhi, a city more accustomed to mystic healing than $21^{*}$ century medicine, a Brisbane mother is seeking out a modern-day miracle." ${ }^{27}$

Embryonic stem cell therapy at NuTech and, more broadly, stem cell therapy and several other transnational medical practices, represent co-production of science and society (Jasanoff 2005), but with a stutter. This stutter, however, cannot be read simply as a result of practices of a particular clinic (or a particular country or region). It also reflects a discursive stutter, wherein the normative discourses - on the basis of which scientific, ethical, and juridical wrong/right and true/false are being assessed-are getting troubled and "deterritorialized." And this stutter is most likely going to get more pronounced as the transnational landscape of technoscience continues to shift.

\section{Expanding the Empirical Approach of STS}

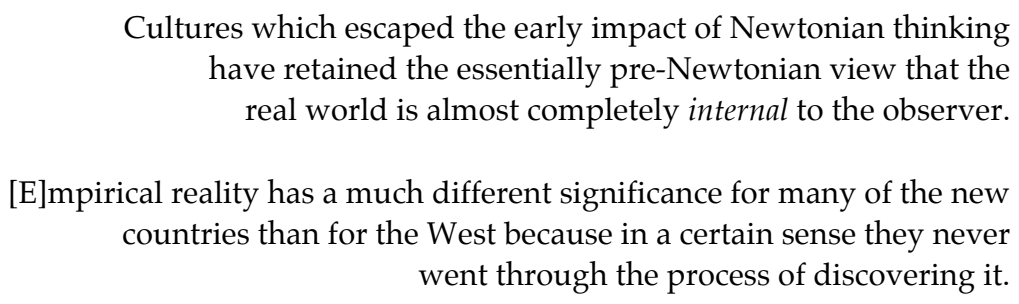

Henry Kissinger, American Foreign Policy, 1977, p. 48-49.

Discourses, as Foucault has shown, are not only articulated as ideas, they are embodied in material spaces and practices, as for example in the prisons and the clinic. Moreover, discourses are expressed through the axis of power/knowledge and travel across geographies and time and become a part of our everyday selves. Edward Said shows this in the case of Orientalism. Orientalist discourse, Said argues, "shares with magic and with mythology the self-containing, self-reinforcing character of a closed system, in which objects are what they are because they are what they are, for once, for all time, for ontological reasons that no empirical material can either dislodge or alter" (Said 1979, 70).

An important contribution of STS lies in disrupting discourses that often become closed systems, for example, nature-culture divide, scientific rationality, or the Scientific Revolution. ${ }^{28}$ And STS does so through an empirical approach. Latour uses an analytical strategy that in a significant way is the opposite of that deployed by Foucault. Instead of excavating "history of the

${ }^{2}$ http:/ / sixtyminutes.ninemsn.com.au/stories/lizhayes/273191/ chasing-a-miracle, accessed July 24, 2015.

${ }_{2 s}$ Steven Shapin, for example, argues, "there is no essence of the Scientific Revolution, yet pragmatic criteria push me at times towards an artificially coherent account of distinctive changes in natural knowledge" (Shapin 1996, 12). 
present," Latour uses the present to displace certain historical constructs. Highlighting natureculture and science-society hybrids in representations and practices of science and technology around us, Latour goes on to suggest "we have never been modern" (Latour 1993).

We, nevertheless, have to be careful in dismissing the role of modernist (and other) discourses in constituting selves, spaces, and practices-including our own-even if such discourses (orientalism, racism, sexism, etc.) may not have empirical basis. These discourses call into question how we see and analyze the role of the "empirical." Henry Kissinger's quotes in the epigraph are illustrative of how a dualist separation of fact and value has been used to express an Orientalist imaginative geography. For Uberoi, such separation of fact and value has been the hallmark of European modernity and modern science, and he traces its origin to the debate in 1529 at the Marburg conference over "whether the true body and blood of Christ are corporeally in the bread and wine." He concludes:

By stating the issue and forcing it in terms of dualism, or more properly double monism, Zwingli had discovered or invented the modern concept of time in which every event was either spiritual or mental or corporeal and material but no event was or could be both at once (Uberoi 1978b, 28).

Uberoi, using a structuralist approach, is interested in a truth or an origin and, as a result, ignores not only the role of contingency and emergence, but also particular geopolitical implications of discursive articulations such as that of Kissinger. Latour and ANT, on the other hand, affirm the role of heterogeneous actors in the "pluriverse," but they also end up recreating the Euro/West-centric divides. ${ }^{29}$ The empirical method of STS, in particular Latour's strategy of using the present to displace dominant histories and discourses, can allow us to investigate the genealogies of dualist divides and to highlight how they are folded within particular geopolitical networks of domination and control.

Ignoring the role of discursive contextures runs the risk of recreating the old divides and in reifying the "other" (and the "self"), even when our intention is to present plurality of "voices." ${ }^{\circ 0}$ As many of us embrace the dominated "other" of dualist hierarchies-- ontology (epistemology), object (subject), non-West (West), or bricoleur (engineer)--it will be useful to remember not only that the "engineer" was a myth created by the "bricoleur," but also that the myth of the "bricoleur" sustained the myth of the "engineer" and with it Euro/West-centrism. De/post-colonial interventions cannot work if we do not interrogate the historical legacy and continuing valence of Euro/West-centric discourses in constituting the "self" and the "other" and in impacting epistemological and ontological interventions. A deconstruction of these discourses may not lead to an inversion of the dualist hierarchy, as I showed through my discussion of

${ }^{2}$ Latour too posits origins, which are often, though not always, shown as the non-center. He, for example, delves into etymology of the term "social" to present another genealogy of sociology: "What I want to do is to redefine the notion of social by going back to its original meaning and making it able to trace connections again"(Latour 2005, 1).

s Emphasizing co-constitution of western modernity and European imperialism, Gyan Prakash counters the Latourian thesis for failing "to take into account empire's constitutive role in the formation of the West and...[for assuming] that it forged its characteristic commitment to modernity before overseas domination" (Prakash 1999, 12). 
embryonic stem cell therapy in a clinic in Delhi. Even if we decide whom to betray (dominant or dominated), let's not forget the "stuttering" that not only troubles the dominant discourses but also does not allow any stable position on either side.

Expressions of Euro/West-centrism are neither incidental nor restricted to the analyses of particular theorists. Following Derrida, I would argue: "The overabundance of signifier, its supplementary character is...the result of a...lack which must be supplemented" (Derrida 1978, 290). That is why I suggest a deconstructive-empirical approach (Prasad 2014b). That is: utilize the empirical approach of STS to displace certain historical constructs and combine it with deconstruction of the associated discourses, which can then allow us to unravel not only the genealogies of knowledge/power that undergird these discourses, but also the complex and hierarchical entangled histories and cultures that go beyond dualist divides. Analysis of discursive contextures, thus, instead of limiting, expands the empirical approach of STS.

\section{Acknowledgements}

I would like to thank Steven Epstein, Daniel Kleinman, Srirupa Prasad, Lucy Suchman, and the anonymous reviewer for their comments and suggestions. The second part of the paper- on embryonic stem cell therapy in India--is based on research funded by an American Institute of Indian Studies and National Endowment for the Humanities fellowship.

\section{References}

Abraham, I. 2000. "Landscape and Postcolonial Science." Contributions to Indian Sociology 34 (2):163-87.

Abraham, I. 2006. "The Contradictory Spaces of Postcolonial Techno-Science." Economic and Political Weekly 41 (3):210-217.

Althusser, L. 1971. Lenin $\mathcal{E}$ Philosophy $\mathcal{E}$ other essays. New York: Monthly Review Press.

Anderson, W. 2002. "Postcolonial Technoscience." Social Studies of Science 32 (5):643-58.

Anderson, W. 2009. "From Subjugated Knowledge to Conjugated Subjects: Science and Globalisation, or Postcolonial Studies of Science?" Postcolonial Studies 12 (4):389-400.

Anderson, W. 2012. "Asia as Method in Science and Technology Studies." East Asian Science, Technology and Society: An International Journal 6 (4):445-451.

Bhabha, H. 1994. The Location of Culture. NewYork: Routledge.

Bharadwaj, A. 2009. "Assisted Life: The Neoliberal Moral Economy of Embryonic Stem Cells in India." In Assisting Reproduction, Testing Genes: Global Encounters with New Biotechnologies, edited by D. Biernbaum-Carmeli and M. C. Inhorn. New York: Berghahn.

Bharadwaj, A. 2015. "Badnam Science? The Spectre of the 'Bad' Name and the Politics of Stem Cell Science in India." Samaj: South Asia Multidisciplinary Academic Journal 12:1-16.

Bowker, G, and S. L. Star. 1999. Sorting Things Out: Classification and its Consequences. Cambridge, MA: MIT Press.

Butler, J. 1990. Gender Trouble. New York: Routledge. 
Chakrabarty, D. 2000. Provincializing Europe: Postcolonial Thought and Historical Difference. Princeton, NJ: Princeton Univ Press.

Cooper, M. 2008. Life as Surplus : Biotechnology and Capitalism in the Neoliberal Era Seattle: University of Washington Press.

Cooper, M. and C. Waldby. 2014. Clinical Labor: Tissue Donors and Research Subjects in the Global Bioeconomy. Durham, NC: Duke University Press.

Dear, P. 1985. "Totius in Verba: Rhetoric and Authority in the Early Royal Society." Isis 76 (2):144161.

Deleuze, G. 1997. Essays Critical and Clinical. Minneapolis: University of Minnesota Press.

Deleuze, G. and F. Guattari. 1987. A Thousand Plateaus: Capitalism and Schizophrenia. Translated by Brian Massumi. Minneapolis: University of Minnesota Press.

Derrida, J. 1978. Writing and Difference. Chicago: University of Chicago Press.

Epstein, S. 1996. Impure Science: AIDS, Activism, and the Politics of Knowledge. Berkeley: University of California Press.

Foucault, M. 1979. Discipline E Punish: The Birth of the Prison. New York: Vintage Books.

Foucault, M. 1980. Power/Knowledge: Selected Interviews and Other Writings, 1972-1977. Translated by C. Gordon, L. Marshall, J. Mepham and K. Soper. Edited by C. Gordon. New York: Pantheon Books.

Foucault, M. 1994. The Birth of the Clinic. New York: Vintage.

Franklin, S. 1995. "Science as Culture, Cultures of Science." Annual Review of Anthropology 24 (1):163-184.

Franklin, S. 2001. "Culturing Biology: Cell Lines for the New Millennium." Health Affairs 5 (3):335-354.

Franklin, S. 2005. "Stem Cells R US: Emergent Life Forms and the Global Biological." In Global Assemblages: Technology, Politics and Ethics as Anthropological Problems, edited by Aihwa Ong and Stephen Collier. New York: Blackwell.

Fujimura, J. 1992. Crafting Science: Standarized Packages, Boundary Objects, \& Translation. Edited by Andrew Pickering, Science as Practice \& Culture. Chicago, IL: Chicago University Press.

Gabr, H., W. A. El-Kheir, O. Ghannam, M. E. El-Fiki, and Y. Salah. 2015. "Intrathecal Autologous Bone Marrow Derived MSC Therapy in Cerebral Palsy: Safety and Short Term Efficacy." American Journal of Bioscience and Bioengineering 3 (4-1):24-29.

Galison, P. 1996. "Computer Simulations and the Trading Zones." In The Disunity of Science: Boundaries, Context, and Power edited by P. Galison and D. Stump, 118-157. Stanford, CA: Stanford University Press.

Hannaway, O. 1986. "Laboratory Design and the Aim of Science: Andreas Libavius versus Tycho Brahe." Isis 77 (4):585-610.

Haraway, D. 1991. Simians, Cyborgs, and Women: The Reinvention of Nature. New York: Routledge.

Harding, S. 1994. "Is Science Multicultural? Challenges, Resources, Opportunities, Uncertainties." Configurations 2 (2):301-330.

Harding, S. 1998. Is Science Multicultural? Postcolonialism, Feminisms and Epistemologies. Bloomington, IN: Indiana University Press. 
Harding, S, ed. 2011. The Postcolonial Science and Technology Studies Reader. Durham, NC: Duke University Press.

Jasanoff, S. 2005. Designs on Nature: Science and Democracy in Europe and the United States. Princeton, NJ: Princeton University Press.

Knorr-Cetina, K 1981. The Manufacture of Knowledge: An Essay on the Constructivist and Contextual Nature of Science. Vol. 26. New York: Peramon Press.

Latour, Bruno. 1987. Science in Action: How to Follow Scientists and Engineers through Society. Cambridge, MA: Harvard University Press.

Latour, B. 1993. We Have Never Been Modern. Translated by Cartherine Porter. Cambridge, MA: Harvard University Press.

Latour, B. 2005. Reassembling the Social: An Introduction to Actor-Network Theory. Oxford, England: Oxford University Press.

Latour, B. and S. Woolgar. 1986. Laboratory Life: The Construction of Scientific Facts. Princeton: Princeton University Press.

Law, J. 1986. "On the Methods of Long-Distance Control: Vessels, Navigation and the Portuguese Route to India." In Power, Action and Belief: A New Sociology of Knowledge, edited by M. Callon and J. Law, 234-263. New York: Routledge.

Lin, W.-Y. and J. Law. 2014. "A correlative STS: Lessons from a Chinese medical practice." Social Studies of Science 44 (6):801-824.

Lynch, M. 1991. "Laboratory Space the Technological Complex: An Investigation of Topical Contextures." Science in Context 4 (1):51-78.

Lynch, M. 1993. Scientific Practice and Ordinary Action: Ethnomethodology and Social Studies of Science. New York: Cambridge University Press.

McNeil, M. 2005. "Postcolonial Technoscience." Science as Culture 14 (2):105-200.

Parthasarthi, P. 2002. "The Great Divergence." Past and Present 176:275-293.

Parthasarthi, Prasannan. 2011. Why Europe Grew Rich and Asia Did Not: Global Economic Divergence, 1600-1850. New York: Cambridge University Press.

Petersen, A. 2009. "The Ethics of Expectations: Biobanks and the Promise of Personalized Medicine." Monash Ethics Review 28 (1):5.1-5.12.

Petersen, A. and K. Seear. 2011. "Technologies of Hope: Techniques of Online Advertising of Stem Cell Treatments." New Genetics and Society 30 (4):329-346.

Pickering, A., ed. 1992. Science as Practice and Culture. Chicago: University of Chicago Press.

Pickering, A. 1995. The Mangle of Practice: Time, Agency, and Science. Chicago: Chicago University Press.

Prakash, G. 1999. Another Reason: Science and the Imagination of Modern India. Princeton, NJ: Princeton University Press.

Prasad, A. 2014a. "Entangled Histories and Imaginative Geographies of Technoscientific Innovations." Science as Culture 23 (3):432-439.

Prasad, A. 2014b. Imperial Technoscience: Transnational Histories of MRI in the United States, Britain, and India. Cambridge, MA: MIT Press. 
Prasad, A. 2015. "Ambivalent Journeys of Hope: Embryonic Stem Cell Therapy in a Clinic in India." Health 19 (2):137-153.

Rheinberger, H.-J. 1997. Toward a History of Epistemic Things: Synthesizing Proteins in the Test Tube. Stanford, CA: Stanford University Press.

Said, E. 1979. Orientalism. New York: Vintage.

Salter, B., M. Cooper, A. Dickins, and V. Cardo. 2007. "Stem Cell Science in India: Emerging Economies and the Politics of Globalization." Regenerative Medicine 2 (1):75-89.

Scher, A. 2013. This is How I Save My Life: A True Story of Embryonic Stem Cells, Indian Adventures, and Ultimate Self-Healing. Amy B. Scher, Publisher.

Seth, S. 2009. "Putting Knowledge in its Place: Science, Colonialism, and the Postcolonial." Postcolonial Studies 12 (4):373-388.

Shapin, S. 1988. "The House of Experiment in Seventeenth-Century England." Isis 79 (3):373-404.

Shapin, S. 1996. The Scientific Revolution. Chicago: University of Chicago Press.

Shapin, S. and S. Schaffer. 1985. Leviathan and the Air-Pump: Hobbes, Boyle and the Experimental Life Princeton, NJ: Princeton University Press.

Shroff, G., A. Gupta, and J. K. Barthakur. 2014. "Therapeutic Potential of Human Embryonic Stem Cell Transplantation in Patients with Cerebral Palsy." Journal of Translational Medicine 12 (318).

Star, S. L. and J. Griesemer. 1989. "Institutional Ecology: Translations \& Boundary Objects: Amateurs and Proffessionals in Berkeley's Museum of Vertebrate Zoology 1907-39." Social Studies of Science 19 (3):387-420.

Subrahmanyam, S. 1993. The Portuguese Empire in Asia, 1500-1700. New Delhi: Longman.

Subrahmanyam, S. 1997. "Connected Histories: Notes Towards a Reconfiguration of Early Modern Eurasia." Modern Asian Studies 31 (3):735-762.

Subrahmanyam, S. 2005. Explorations in Connected History. From the Tagus to the Ganges. Delhi: Oxford University Press.

Traweek, S. 1988. Beamtimes and Lifetimes: The World of High Energy Physicists. Cambridge, MA: Harvard University Press.

Trounson, A. and C. McDonald. 2015. "Stem Cell Therapies in Clinical Trials: Progress and Challenges." Cell Stem Cell 17 (1):11-22.

Uberoi, J. P. S. 1978a. "The Structural Concept of Asian Frontier." In History and Society: Essays in Honour of Professor Nilanjan Ray, edited by D. Chattopadhyaya, 67-77. Calcutta: K. P. Bagchi.

Uberoi, J.P.S. 1978b. Science and Culture. Delhi: Oxford University Press.

Uberoi, J.P.S. 1984. The Other Mind of Europe: Goethe as a Scientist. Delhi: Oxford University Press.

Uberoi, J.P.S. 2002. The European Modernity: Science, Truth and Method. Delhi: Oxford University Press. 